ISSN 0258-7122 (Print), 2408-8293 (Online)

Bangladesh J. Agril. Res. 42(4): 599-607, December 2017

\title{
EFFICACY OF FUNGICIDES IN CONTROLLING FUSARIUM WILT OF GLADIOLUS
}

\author{
L. YASMIN ${ }^{1}$, M. A. ALI ${ }^{2}$ AND F. N. KHAN ${ }^{3}$
}

\begin{abstract}
The efficacy of fungicides in controlling Fusarium wilt of gladiolus was studied at Horticulture Research Centre (HRC), Bangladesh Agricultural Research Institute (BARI), Gazipur during 2010-2012 following RCB design with four replications. Six fungicides such as Bavistin $(0.1 \%)$, Provax (0.2\%), Mancozeb (0.2\%), Rovral (0.2\%), Chlorax (10\%) and Cupravit $(0.7 \%)$ were evaluated against the Fusarium wilt disease of gladiolus (Fusarium oxysporum f. sp. gladioli) under naturally infested field condition. Bavistin was very effective in reducing the disease incidence and thereby resulting maximum corm germination $(99.98 \%)$, spike length $(73.90 \mathrm{~cm})$, rachis length $(43.70 \mathrm{~cm})$, florets spike ${ }^{-1}(12.63)$, flower sticks plot $^{-1}$ (38.75) and corm plot ${ }^{-1}(60.23)$ and cormel yield ha$(2.51 \mathrm{t})$ of gladiolus. Provax and Cupravit were also effective in inhibiting the disease incidence as well as better spike length, rachis length, florets spike ${ }^{-1}$, no of flower sticks, corm and cormel yield.
\end{abstract}

Keywords: Gladiolus, Fusarium oxysporum f. sp. gladioli, Fusarium wilt, Bavistin, Provax and Cupravit

\section{Introduction}

Gladiolus (Gladiolus sp) is one of the most popular commercial flower in Bangladesh. The agro-ecological conditions of the country are very conducive for the survival and culture of gladiolus. The major production belts of this flower are Jessore sadar, Sharsha, Jhikargacha, Kushtia, Chuadanga, Satkhira, Khulna, Chittagong, Mymensingh, Dhaka, Savar and Gazipur. It has great economic value as a cut-flower and its cultivation is relatively easy. Income from gladiolus flower production is six times higher than that of rice (Momin, 2006).

The major obstacle of gladiolus cultivation in Subtropical and Mediterranean regions is the diseases caused by fungi, bacteria and viruses of which Fusarium wilt disease caused by $F$. oxysporum $\mathrm{f}$. sp. gladioli is a major problem in all over the gladiolus growing areas. Fusarium wilt of gladiolus is considered as a serious and highly devastating disease which can cause $60-70 \%$ yield loss (Vlasova and Shitan, 1974) and the damage may reach upto 100\% (Pathania and Misra, 2000).

\footnotetext{
${ }^{1 \& 3}$ Senior Scientific Officer, Horticulture Research Centre, Bangladesh Agricultural Research Institute (BARI), Joydebpur, Gazipur 1701, ${ }^{2}$ Professor, Department of Plant Pathology, Bangladesh Agricultural University (BAU), Mymensingh, Bangladesh.
} 
Crop loss of $30 \%$ in Germany and $60-80 \%$ in Russia was estimated due to Fusarium wilt of gladiolus (Bruhn, 1955). It is also a serious problem in India and reduced plant growth and flowering upto $15-28 \%$ in the number of florets/spike (Misra et al., 2003).

The pathogen is both seed and soil borne (Cohen and Hass, 1990; Mukhopadhyay, 1995). It causes curving, blending, arching, stunting, yellowing and drying of leaves associated with root and corm rot in the field as well as in the storage. $F$. oxysporum f. sp. gladioli causes three types of rot e.g. vascular corm rot, brown rot and basal rot (Partridge, 2003). Vascular rot is also called yellows and is characterized by a brown discoloration in the centre of the corm and extending into the flesh. The leaf symptoms start at the tip of the leaf blade and gradually spread all over the leaf blade. If the plant is infected at later stage, it produces weak or small florets. When the plant is infected at early stage and infection is severe, whole plant becomes dry and dies within few days (Misra and Singh, 1998).

A study on chemical control of Fusarium wilt and corm rot of gladiolus was carried out by Singh and Arora (1994). They reported that Bavistin- $\mathrm{HCl}$ and Emisan as better fungicides in reducing disease severity (\%) and enhancing corm and cormel yield. Fulsundar et al. (2009) found Carbendazim as effective chemical in disease control of gladiolus. Treatments of corms with chemical before planting also proved to be better as compared to treatment of corms immediately after harvest (Chandel and Bhardwaj, 2000). Corm dips in Benlate, Captan and Carbendazim solution for 15- 60 minutes was effective in controlling Fusarium and other diseases of gladiolus (Magie, 1992). Considering the above situation the present work was under taken to find out an effective chemical for controlling Fusarium wilt disease (Fusarium oxysporum f. sp. gladioli) of gladiolus.

\section{Materials and Methods}

The experiment was conducted at the Floriculture Field under the Horticulture Research Centre (HRC) of Bangladesh Agricultural Research Institute (BARI), Gazipur during the period of 2010-2012. The experiment was set in previously Fusarium oxysporum f. sp. gladioli infested soil. It was laid out in the Randomized Complete Block Design (RCBD) with four replications. The treatments were (1) Corm treatment + soil drenching with Bavistin $(0.1 \%)$, (2) Corm treatment + soil drenching with Mancothane (0.2\%), (3) Corm treatment + soil drenching with Rovral $(0.2 \%)$, (4) Corm treatment + soil drenching with Provax $(0.2 \%)$, (5) Corm treatment + soil drenching with Chlorax (10\%), (6) Corm treatment + soil drenching with Cupravit $(0.7 \%)$ and (7) Control (normal water). 
Corms were deeped in the solution of the fungicides for 15 minutes. The corms were sown in the field. The soil around the base of the plants was subsequently drenched with the respective fungicidal solutions at $200 \mathrm{ml} / \mathrm{hill}$. The first drench was done at 45 days after sowing (DAS) and the second drench was at 75 DAS.

The recommended dose of fertilizers cowdung @10 t/ha, TSP @ $225 \mathrm{~kg} / \mathrm{ha}$ and MoP $190 \mathrm{~kg} / \mathrm{ha}$ were applied to the soil during land preparation and thoroughly mixed with the soil. Urea @ $200 \mathrm{~kg} / \mathrm{ha}$ was top dressed in two equal splits, one at the four leaf stage and another at spike initiation stage (Woltz, 1976).

The unit plot size was $1.25 \mathrm{~m} \times 1.6 \mathrm{~m}$. Spacing was maintained at $25 \mathrm{~cm}$ between the rows and $20 \mathrm{~cm}$ between the plants. Depth of planting of the corms was $6 \mathrm{~cm}$. Two adjacent unit plots were separated by $50 \mathrm{~cm}$ space, and there was $75 \mathrm{~cm}$ space between the blocks. Germination (\%), Plant height $(\mathrm{cm})$, Spike length $(\mathrm{cm})$, Rachis length $(\mathrm{cm})$, Florets spike ${ }^{-1}$, Flower stick weight $(\mathrm{g})$, Flower sticks plot $^{-1}$, Flower sticks ha ${ }^{-1}$, Pre-germination corm rot (\%), Wilted plant (\%), Disease incidence (\%), Percent disease index (PDI), Corms hill ${ }^{-1}$, Corm yield, Cormels hill ${ }^{-1}$ and Cormels yield (g) were rcorded. The disease incidence, Percent disease index and wilted plant were calculated using following formula (Singh and Arora, 1994):

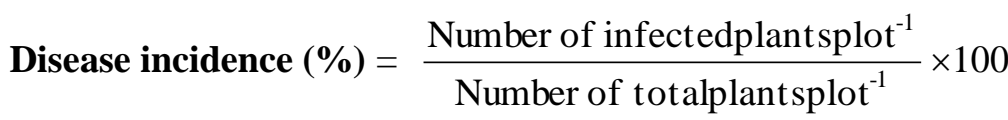

Percent disease index $(\%)=\frac{\text { Class frequency }}{\text { Totalnumber of sample } x \text { Maximum grade of scale }} \times 100$

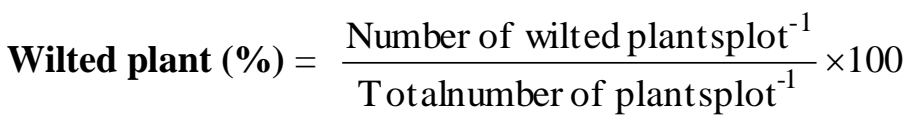

\section{Results and Discussion}

All the parameters of vegetative growth except plant height of gladiolus showed significant variations among the treatments (Table 1). The highest percentage of corms $(99 \%)$ germinated in Bavistin. It was statistically similar to Provax and Cupravit. The lowest percentage of corms $(93 \%)$ germinated in control. The other treatments were statistically similar (96\% to $97 \%$ ).

The minimum days required for germination of 50\% of the corms in case of Bavistin and it was similar to Rovral, Provax, Mancozeb and Chlorax. The maximum days (13) required to germinate $50 \%$ corms in the control plot. Cupravit, Chlorax, Mancozeb and Provax were statistically similar in case of $50 \%$ corms germination. 
Table 1. Effect of corm treatment and soil drenching with fungicides on vegetative growth of gladiolus

\begin{tabular}{|c|c|c|c|}
\hline Treatments & $\begin{array}{c}\text { Germination } \\
(\%)\end{array}$ & $\begin{array}{c}\text { Days to } 50 \% \\
\text { germination }\end{array}$ & $\begin{array}{c}\text { Plant height } \\
(\mathrm{cm})\end{array}$ \\
\hline Mancozeb $(0.2 \%)$ & $\begin{array}{l}97 \mathrm{bc} \\
(9.84)\end{array}$ & $12 \mathrm{abc}$ & 36.50 \\
\hline Rovral $(0.2 \%)$ & $\begin{array}{l}97 \mathrm{bc} \\
(9.84)\end{array}$ & $11.50 \mathrm{bc}$ & 35.63 \\
\hline Bavistin (0.1\%) & $\begin{array}{l}99 \mathrm{a} \\
(9.94)\end{array}$ & $10.75 \mathrm{c}$ & 37.25 \\
\hline Provax $(0.2 \%)$ & $\begin{array}{l}98 \mathrm{ab} \\
(9.90)\end{array}$ & $11.75 \mathrm{abc}$ & 36.50 \\
\hline Chlorax $(0.2 \%)$ & $\begin{array}{c}96 \mathrm{c} \\
(9.78)\end{array}$ & $12.00 \mathrm{abc}$ & 36.88 \\
\hline Cupravit $(0.7 \%)$ & $\begin{array}{l}98 \mathrm{ab} \\
(9.87)\end{array}$ & $12.25 \mathrm{ab}$ & 36.00 \\
\hline Control & $\begin{array}{l}93 \mathrm{~d} \\
(9.65) \\
\end{array}$ & $13.00 \mathrm{a}$ & 35.50 \\
\hline $\mathrm{CV}(\%)$ & 0.43 & 6.62 & 4.16 \\
\hline
\end{tabular}

Means followed by the same letters in a column did not differ significantly at the 5\% level of probability. Values within paranthesis were suare root transformation.

Table 2. Effect of corm treatment and soil drenching with fungicides on the disease incidence of gladiolus

\begin{tabular}{l|c|c|c}
\hline Treatments & $\begin{array}{c}\text { Pre-germination corm } \\
\text { rot }(\%)\end{array}$ & Wilted plant $(\%)$ & $\begin{array}{c}\text { Disease severity } \\
(\text { PDI })\end{array}$ \\
\hline Mancozeb & $3.63 \mathrm{bc}$ & $5.02 \mathrm{c}$ & $27.50 \mathrm{bc}$ \\
Rovral & $(1.89)$ & $(2.22)$ & $(30.50)$ \\
& $3.63 \mathrm{bc}$ & $4.38 \mathrm{c}$ & $27.50 \mathrm{bc}$ \\
Bavistin & $(1.89)$ & $(2.07)$ & $(30.50)$ \\
& $1.75 \mathrm{~d}$ & $3.03 \mathrm{~d}$ & $25.63 \mathrm{c}$ \\
Provax & $(1.22)$ & $(1.74)$ & $(29.28)$ \\
& $2.38 \mathrm{~cd}$ & $3.05 \mathrm{~d}$ & $26.25 \mathrm{bc}$ \\
Chlorax & $(1.48)$ & $(1.75)$ & $(29.65)$ \\
& $4.88 \mathrm{~b}$ & $6.39 \mathrm{~b}$ & $28.75 \mathrm{ab}$ \\
Cupravit & $(2.20)$ & $(2.52)$ & $(31.24)$ \\
& $3.00 \mathrm{c}$ & $4.35 \mathrm{c}$ & $26.88 \mathrm{bc}$ \\
Control & $(1.73)$ & $(2.06)$ & $(30.05)$ \\
& $7.38 \mathrm{a}$ & $9.11 \mathrm{a}$ & $30.63 \mathrm{a}$ \\
CV $(\%)$ & $(2.71)$ & $(3.01)$ & $(32.38)$ \\
\hline
\end{tabular}

Means followed by the same letters in a column did not differ significantly at the $5 \%$ level of probability. Values within paranthesis were suare root transformation. 
Corm treatment by fungicides showed significant effect on the pre-germination corm rot (Table 2). The highest pre-germination corm rot $(7.38 \%)$ was recorded in control where no fungicide was used. The pre - germination corm rot was low $(1.75 \%)$ in Bavistin and Provax $(2.38 \%)$. The other treatments showed similar effects (3.63 to $4.88 \%$ ). Wilted plant varied from 3.03 to $9.11 \%$. The highest wilted plant $(9.11 \%)$ was recorded in control plot and the lowest wilted plant (3.03\%) was observed in Bavistin treated plots. The range of wilted plant in other treatments varied from 4.35 to $6.39 \%$. The disease severity (PDI) was high (30.63\%) in control plot and low (25.63\%) in plots where Bavistin was applied. The PDI was statistically similar in Provax, Cupravit, Mancozeb and Rovral treated plots.

The effect of fungicides on flower production of gladiolus showed significant variations among themselves (Table 3). Minimum days (76) were needed by Bavistin to 50\% spike initiation, where Cupravit, Chlorax and Provax were similar in days to $50 \%$ spike initiation. The maximum days (79) needed to $50 \%$ spike initiation in control.

Table 3. Effect of corm treatment and soil drenching with fungicides on flower production of gladiolus

\begin{tabular}{l|l|l|l|l|l}
\hline Treatments & $\begin{array}{c}\text { Days to 50\% } \\
\text { spike initiation }\end{array}$ & $\begin{array}{c}\text { Spike length } \\
(\mathrm{cm})\end{array}$ & $\begin{array}{c}\text { Florets } \\
\text { spike }^{-1}\end{array}$ & $\begin{array}{c}\text { Flower stick } \\
\text { weight }(\mathrm{g})\end{array}$ & $\begin{array}{c}\text { Flower stick } \\
\text { plot }^{-1}\end{array}$ \\
\hline Mancozeb & $78 \mathrm{ab}$ & $66.0 \mathrm{abc}$ & $11.88 \mathrm{abc}$ & $59.75 \mathrm{~cd}$ & $35.75 \mathrm{bc}$ \\
Rovral & $78 \mathrm{ab}$ & $65.75 \mathrm{bcd}$ & $11.75 \mathrm{bc}$ & $59.50 \mathrm{~cd}$ & $35.25 \mathrm{c}$ \\
Bavistin & $76 \mathrm{c}$ & $66.75 \mathrm{a}$ & $12.25 \mathrm{a}$ & $61.25 \mathrm{a}$ & $37.50 \mathrm{a}$ \\
Provax & $77 \mathrm{abc}$ & $66.63 \mathrm{ab}$ & $12.13 \mathrm{ab}$ & $60.75 \mathrm{ab}$ & $36.50 \mathrm{~b}$ \\
Chlorax & $77 \mathrm{bc}$ & $65.50 \mathrm{~cd}$ & $11.50 \mathrm{c}$ & $59.0 \mathrm{de}$ & $35.0 \mathrm{c}$ \\
Cupravit & $77 \mathrm{bc}$ & $66.50 \mathrm{ab}$ & $12.0 \mathrm{ab}$ & $60.25 \mathrm{bc}$ & $36.25 \mathrm{~b}$ \\
Control & $79 \mathrm{a}$ & $65.0 \mathrm{~d}$ & $11.00 \mathrm{~d}$ & $58.25 \mathrm{e}$ & $33.75 \mathrm{~d}$ \\
\hline \multicolumn{1}{c}{$\mathrm{CV}(\%)$} & 1.35 & 0.91 & 2.58 & 0.95 & 1.52 \\
\hline
\end{tabular}

Means followed by the same letters in a column did not differ significantly at the 5\% level of probability.

Bavistin produced the longest spike $(66.75 \mathrm{~cm})$ and it was statistically identical to Provax, Cupravit and Mancozeb. Other treatments produced $65.0 \mathrm{~cm}$ to 65.75 $\mathrm{cm}$ long spikes.

Maximum number of florets spike ${ }^{-1}(12.25)$ was recored in Bavistin and it was statistically similar to Provax, Cupravit and Mancozeb. Control treatment plots produced the minimum number of florets spike ${ }^{-1}(11)$. The number of florets spike $^{-1}$ was 11.50 to 11.75 in other treatments. 
The stick weight was $61.25 \mathrm{~g}$ in Bavistin which was similar to Provax. The stick weight was $58.25 \mathrm{~g}$ in the control plots. The range of stick weight in other treatments was $59 \mathrm{~g}$ to $60.25 \mathrm{~g}$. The maximum number of flower sticks (37.50) plot $^{-1}$ was recorded in the treatment Bavistin. The minimum number of flower sticks (33.75) plot $^{-1}$ was recorded in control. The number of flower sticks was 36.25 plot $^{-1}$ in Cupravit and 36.50 plot $^{-1}$ in Provax and it ranged from 35.0 to 35.75 plot $^{-1}$ in other treatments.

Disease incidence was low in case of using Bavistin consequently number of flower sticks ha ${ }^{-1}$ was high (Fig. 1). Number of flower sticks ha ${ }^{-1}$ was low in control where disease incidence was high. Number of flower sticks $\mathrm{ha}^{-1}$ was nearly equal in Chlorax, Rovral and Mancozeb. Disease incidence of Fusarium wilt was high in control plot where rachis length was low (Fig. 1). Disease incidence was low in Bavistin where rachis length was high. Provax and Cupravit also reduced disease incidence.

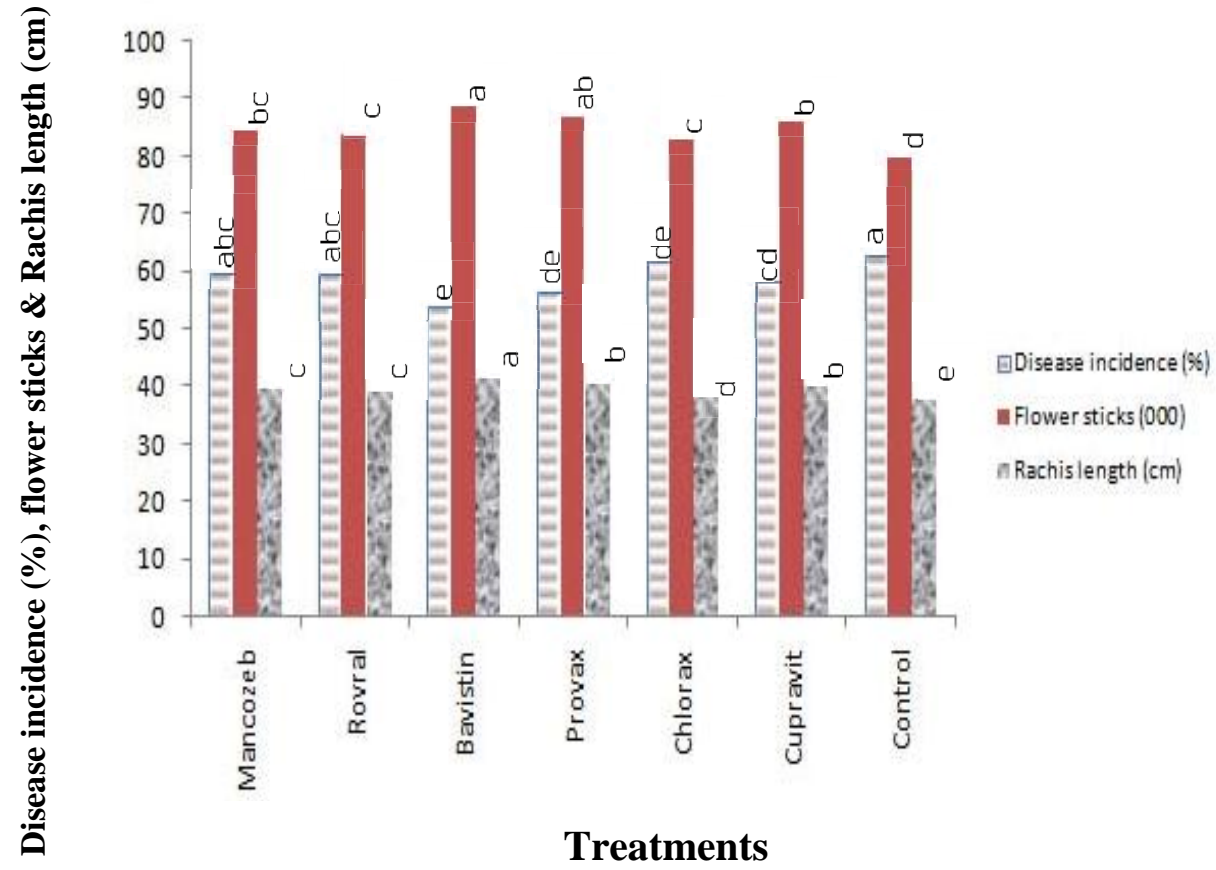

Fig. 1. Effect of fungicides on disease incidence (\%), flower sticks $\left(\mathrm{ha}^{-1}\right)$ and rachis length of gladiolus

All the parameters of corm production except corm diameter showed significant variations by different fungicides (Table 4). The number of corms hill ${ }^{-1}$ in Provax, Mancozeb, Bavistin, Cupravit, Rovral and Chlorax were statistically similar. The minimum number of corms $\left(1.43 \mathrm{hill}^{-1}\right)$ was observed in the control treatment. The corm weight was $19.25 \mathrm{~g}$ in Bavistin and Provax and it was minimum in control plot. Considering diameter, there was no significant 
differences among the treatments. Provax produced 59.28 corms plot $^{-1}$ and 141140 corms ha $^{-1}$ which were statistically identical to Bavistin, Mancozeb and Cupravit. The corms plot ${ }^{-1}$ was 48.43 and ha- ${ }^{-1}$ was 115310 in control. Corms plot ${ }^{1}$ and ha ${ }^{-1}$ were statistically similar in Rovral and Chlorax treated plots.

Table 4. Effect of corm treatment and soil drenching with fungicides on corm production of gladiolus

\begin{tabular}{l|c|c|c|c|c}
\hline \multicolumn{1}{c}{ Treatments } & $\begin{array}{c}\text { Corms } \\
\text { hill }^{-1}\end{array}$ & $\begin{array}{c}\text { Corm weight } \\
(\mathrm{g})\end{array}$ & $\begin{array}{c}\text { Corm } \\
\text { diameter }(\mathrm{cm})\end{array}$ & $\begin{array}{c}\text { Corms } \\
\text { plot }^{-1}\end{array}$ & $\begin{array}{c}\text { Corms } \\
\text { ha }^{-1}(000)\end{array}$ \\
\hline Mancozeb & $1.55 \mathrm{a}$ & $18.00 \mathrm{~b}$ & 3.62 & $57.33 \mathrm{ab}$ & $136.50 \mathrm{ab}$ \\
Rovral & $1.50 \mathrm{ab}$ & $17.75 \mathrm{~b}$ & 3.53 & $55.83 \mathrm{bc}$ & $132.93 \mathrm{bc}$ \\
Bavistin & $1.53 \mathrm{a}$ & $19.25 \mathrm{a}$ & 3.85 & $58.73 \mathrm{ab}$ & $139.83 \mathrm{ab}$ \\
Provax & $1.55 \mathrm{a}$ & $19.25 \mathrm{a}$ & 3.80 & $59.28 \mathrm{a}$ & $141.14 \mathrm{a}$ \\
Chlorax & $1.50 \mathrm{ab}$ & $17.50 \mathrm{~b}$ & 3.46 & $53.95 \mathrm{c}$ & $128.45 \mathrm{c}$ \\
Cupravit & $1.53 \mathrm{a}$ & $19.00 \mathrm{a}$ & 3.78 & $57.18 \mathrm{ab}$ & $136.14 \mathrm{ab}$ \\
Control & $1.43 \mathrm{~b}$ & $15.50 \mathrm{c}$ & 3.51 & $48.43 \mathrm{~d}$ & $115.31 \mathrm{~d}$ \\
\hline CV $(\%)$ & 3.49 & 3.49 & 5.50 & 3.64 & 3.64 \\
\hline
\end{tabular}

Means followed by the same letters in a column did not differ significantly at the $5 \%$ level of probability.

The effect of some chemicals on cormel production showed significant variations except cormels hill ${ }^{-1}$ and cormel weight hill-1 (Table 5). Maximum cormel yield $\operatorname{plot}^{-1}(848 \mathrm{~g})$ and $\mathrm{ha}^{-1}(2.02 \mathrm{t})$ were produced by the treatment of Bavistin which was statistically identical to Provax, Cupravit, Chlorax, Rovral and Mancozeb. Minimum cormel yield plot $^{-1}$ and ha $^{-1}$ were $711 \mathrm{~g}$ and $1.55 \mathrm{t}$ respectively in control plots.

Table 5. Effect of corm treatment and soil drenching with fungicides on cormel production of gladiolus

\begin{tabular}{l|c|c|c|c}
\hline \multicolumn{1}{c|}{ Treatments } & $\begin{array}{c}\text { Cormels hill } \\
1\end{array}$ & $\begin{array}{c}\text { Cormel weight } \\
\text { hill }^{-1}(\mathrm{~g})\end{array}$ & $\begin{array}{c}\text { Cormel yield } \\
\text { plot }^{-1}(\mathrm{~g})\end{array}$ & $\begin{array}{c}\text { Cormel yield } \\
\text { ha }^{-1}(\mathrm{t})\end{array}$ \\
\hline Mancozeb & 16.13 & 20.18 & $744 \mathrm{ab}$ & $1.77 \mathrm{ab}$ \\
Rovral & 17.50 & 20.33 & $757 \mathrm{ab}$ & $1.80 \mathrm{ab}$ \\
Bavistin & 18.00 & 22.00 & $848 \mathrm{a}$ & $2.02 \mathrm{a}$ \\
Provax & 17.38 & 21.55 & $824 \mathrm{a}$ & $1.96 \mathrm{a}$ \\
Chlorax & 17.40 & 21.28 & $765 \mathrm{ab}$ & $1.82 \mathrm{ab}$ \\
Cupravit & 16.75 & 21.30 & $798 \mathrm{a}$ & $1.90 \mathrm{a}$ \\
Control & 15.75 & 19.23 & $652 \mathrm{~b}$ & $1.55 \mathrm{~b}$ \\
\hline CV\% & 15.10 & 10.02 & 9.93 & 9.95 \\
\hline
\end{tabular}

Means followed by the same letters in a column did not differ significantly at the 5\% level of probability. 
The results of present investigation revealed that Bavistin, Provax and Cupravit were effective fungicides for controlling Fusarium wilt disease of gladiolus and thereby producing better vegetative growth of the crop. Chauhan et al. (1988) suggested that a pre-sowing drenching with carbendazim or carboxin reduced wilt and root rot diseases caused by Fusarium sp. Singh and Arora (1994) reported that Bavistin- $\mathrm{HCl}$ and Emisan 6 were the best fungicides in reducing disease severity (\%) of Fusarium yellows and corm rot ( $F$. oxysporum f. sp. gladioli) of gladiolus. Hanks (1996) reported that double treatment with fungicides such as carbendazim, chlorothanil and benomyl were very effective against this disease. Shakir et al. (1998) observed that corm sprouting and plant height was considerably reduced by $F$. oxysporum f. sp. Gladioli and corm sprouting was improved when rotted corms were sown after dipping in the fungicide. They reported that Bavistin followed by Dithane M-45 proved to be the best fungicide for the control of $F$. oxysporum f. sp. gladioli. Fulsundar et al. (2009) found carbendazim treatment was most effective in disease control as well as improving the plant height, spike length, corm weight and cormels.

\section{Conclusion}

Bavistin $(0.1 \%)$ used as corm treatment and soil drenching showed the best performance in reducing Fusarium wilt of gladiolus and thereby resulting maximum germination, spike length, rachis length, florets spike ${ }^{-1}$, flower sticks, corm and comel yield. Provax and Cupravit were also effective in inhibiting the disease incidence as well as better spike length, rachis length, florets spike ${ }^{-1}$, flower sticks, corm and cormel yield.

\section{References}

Bruhn. 1955. Untersuchungen uber die Fusarium krankheit de gladiolen. Phytopathology, 25: $1-38$.

Chandel, S.S. and L.N. Bhardwaj. 2000. Effect of sowing dates and fungcidal treatment on the management of Fusarium wilt of gladiolus. Plant Dis. Res., 15(1): 24-27.

Chauhan, M.S., J.P.S. Yadav and S. Gangopadhayay. 1988: Chemical control of soil borne fungal pathogen complex of seedlings of cotton. Tropical Pest Manag., 34:159-161.

Cohen, A. and H.V. Hass. 1990. Hot water treatment tolerance in gladiolus cormels and their state of dormancy. Agril. Res. Org., The Volcani Centre, Israel. 495- 503.

Fulsundar A., T. Pillai and K.S. Thakur. 2009. Biological and chemical management of gladiolus corm rot. J. Soils Crops, 19: 135- 138.

Hanks, G.R. 1996. Control of Fusarium oxysporum f. sp.narcissi. The cause of narcissus basal rot with thiabendazole and other fungicides. Crop Protec. 15: 549-558.

Magie, R.O. 1992. Effectiveness of Benlate/ Captan dip in controlling Fusarium disease of gladiolus in relation to $\mathrm{p}^{\mathrm{H}}$ and temperature of the dip. NAGC Bull., 192(190): 35-36. 
Misra, R.L. and B. Sngh. 1998. Gladiolus. In: Commercial Flowers. (Eds) Bose, T. K. and L. P. Yadav. Naya Prokash, Calcutta, India. Pp. 266-353.

Misra, R.L., B. Sing and S.K. Palai. 2003. Galdiolus. In. Commercial Flowers. Vol-2. $2^{\text {nd }}$ Rev. ed. Nayaprokash. Calcutta, India. Pp. 1-113.

Momin, M.A. 2006. Floriculture Survey in Bangladesh. A Consultancy Report. FAO/ UNDP (IHNDP/BGD/97/06)

Mukhopadhyay, A. 1995. Gladiolus. Publication and Information Division. Indian Council of Agric. Res., Krishi Anusandhan Bhavan, New Delhi. Pp.1-83.

Pathania, N.S. and R.I. Misra. 2000. In vitro mutagenesis studies in gladiolus for induction of resistance to Fusarium oxysporum f. sp. gladioli. International Horticultural Congress: Elegant Science in Floriculture. Acta Horticulturae 624, 26.

Partridge, J.E. 2003. Fusarium rot and yellows of gladiolus. Department of Plant Pathology, University of Nebraska, Lincoln, NE, USA, 47 P.

Shakir, A.S., E. Haq and Ayub. 1998. Studies on pathogenecity and eradication of some fungal diseases of gladiolus in Pakistan. Pakistan J. Biol. Sci., 1(1): 23-26.

Singh, P.J. and J.S. Arora. 1994. Chemical control of Fusarium yellows and corm rot (Fusarium oxysporum f. sp. gladioli) of gladiolus. Oxford and IBH publishing Co. Pvt. Ltd. Calcutta. Pp. 461- 462.

Vlasova, V. J. and N. Shitan. 1974. Means of increasing resistance of plant to Fusarium wilt NAUCHN TRUDY STRAVROOL SK 37: 127-133.

Woltz, S.S. 1976. Fertilization of gladiolus. Gladio Grams, NAGC, No. 21: 1-5. 
